\title{
Kształtowanie rozumienia sfery życia uczuciowego u przedszkolaków - nowe rozwiązania
}

Niniejszy tekst podejmuje problematykę rozumienia sfery życia uczuciowego u przedszkolaków. W pierwszej części rozważań omówiono zagadnienia związane $\mathrm{z}$ teoretyczną analizą rozumienia emocji przez dzieci w kontekście badań dotyczących inteligencji emocjonalnej, następnie przedstawiono procedurę badawczą oraz wyniki badań własnych. Zgromadzono dane dotyczące konceptualizacji uczuć w języku i pracach plastycznych sześciolatków. Pozwoliły one ocenić w jaki sposób dzieci interpretują zdarzenia, które wywołują emocje oraz jak ustosunkowują się uczuciowo do nich.

Wyniki przedstawionych badań nie udzielają jednoznacznych wskazówek dotyczących wspierania inteligencji emocjonalnej sześciolatków, sugerują sposoby realizacji określonych celów wychowania emocjonalnego.

W ujęciu D. Golemana ${ }^{1}$ inteligencja emocjonalna stanowi zbiór zdolności, typu samokontrola, zapat, wytrwałość $i$ zdolność motywacji, które możemy kształcić przez całe życie, okresem zaś najbardziej krytycznym dla rozwoju tych zdolności jest średnie i późne dzieciństwo. Już pod koniec lat dziewięćdziesiątych ubiegłego stulecia zaczęto mówić o edukacji emocjonalnej, której celem jest uczyć jak najlepiej czuć i jak najwłaściwiej się zachowywać Według J. Duun² dzieci już we wczesnej ontogenezie okazują zaciekawienie tym, co inni ludzie czują i dlaczego to czuja, co wyraża się w zadawanych przez nie pytaniach, natomiast Eisenberg i Fabes ${ }^{3}$ podsumowując swoje badania nad rozwojem ekspresji emocjonalnej i rozumieniem emocji, stwierdzili, że czterolatki w porównaniu z trzylatkami bardziej bezpośrednio okazują akceptację i uczucia swoim przyjaciołom oraz częściej reagują na cierpienie czy smutek innych osób, co wskazuje na ciągły rozwój tych zdolności. Podstawą rozumienia uczuć innych ludzi jest umiejętność ich rozpoznawania u siebie i innych. Zdaniem Lane'a i Schwarza ${ }^{4}$ doświadczenie

\footnotetext{
${ }^{1}$ D. Goleman, Inteligencja emocjonalna, Poznań 1997.

2 J. Dunn, Przyjaźnie dzieci, Kraków 2008.

${ }^{3}$ Tamże.

${ }^{4}$ D. Szczygieł, A. Kolańczyk, Skala poziomów świadomości własnych emocji, Roczniki Psychologiczne, Warszawa 2000, t. 3. s. 155-179.
} 
przeżyć emocjonalnych znajduje swoje odzwierciedlenie w werbalnych reprezentacjach jednostki i przebiega tymi samymi etapami jak rozwój procesów poznawczych opisanych przez J. Piageta ${ }^{5}$.

Jako pierwsi precyzyjnie zdefiniowali pojecie inteligencji emocjonalnej Salovey, Mayer jako zdolność do operowania na materiale dotyczacym emocji swoich lub innych ludzi, a zatem zdolność do rozpoznawania własnych emocji oraz stanów emocjonalnych innych ludzi, umiejętność rozumienia sygnatów świadczacych o zaistnieniu takich, a nie innych emocji oraz umiejętność magazynowania i przetwarzania wiedzy dotyczacej emocji w celu regulacji swojego zachowania $w$ taki sposób, by dażyć do rozwoju emocjonalnego $i$ intelektualnego ${ }^{6}$. Salovey, Mayer i Caruso są autorami czteroskładnikowego modelu pomiaru inteligencji emocjonalnej - MSCEIT, składającego się z czterech grup zdolności:

\section{- spostrzegania emocji}

- wykorzystywania emocji do wspomagania myślenia

- rozumienia emocji

- zarzqdzania emocjami

Spostrzeganie emocji dotyczy umiejętności ich percepcji u siebie i innych, a także w odniesieniu do dzieł sztuki, opowieści, muzyki. Wykorzystywanie emocji do wspomagania myślenia wiąże się ze zdolnością do ich odczuwania i wyrażania oraz adaptowania emocji do wzbogacania i podtrzymywania procesów poznawczych. Natomiast wymiar rozumienia emocji obejmuje przede wszystkim zdolność do analizowania informacji emocjonalnych oraz świadomość, iż emocje najczęściej łączą się ze sobą tworząc określone stany, oraz że stany te ulegają ciągłym zmianom. Zarządzanie emocjami obejmuje umiejętności regulowania emocji zarówno u siebie jak i u innych. Składnik ten składa się z dwóch skal: pierwsza szacuje jak osoba badana zarządza emocjami innych, jest to- zarzqdzanie społeczne, druga, jak jednostka reguluje własne procesy emocjonalne, jest to - zarzqdzanie emocjonalne ${ }^{7}$.

\section{Badania własne}

Założenie wyjściowe:

Dokonać pomiaru inteligencji emocjonalnej u przedszkolaków w ramach modelu MSCEIT.

Badaniami zostały objęte dzieci sześcioletnie w dwóch przedszkolach w Krakowie. Każde dziecko zostało zbadane indywidualnie w warunkach

\footnotetext{
${ }^{5}$ J. Piaget, Jak dziecko sobie wyobraża świat, Warszawa 2006.

${ }^{6}$ P. Salovey, D. J. Sluyter, Inteligencja emocjonalna. Fakty, mity, kontrowersje, Warszawa 1999, s. 71.

${ }^{7}$ A. Brackett, P. Salovey, Pomiar inteligencji emocjonalnej skalq Mayer-Salovey-Caruso Emotional Intelligence Test, s. 114.
} 
izolowanych. Badania przeprowadzono w grudniu 2009 roku oraz w marcu 2010 roku.

Pomiar IE przeprowadzono w zakresie trzech składników skali MSCIET:

Tabela 1. Składniki inteligencji Emocjonalnej mierzone skalą MSCEIT:

\begin{tabular}{|l|l|}
\hline \multicolumn{1}{|c|}{ Składniki } & \multicolumn{1}{|c|}{ Pomiar Inteligencji Emocjonalnej } \\
\hline Spostrzeganie emocji & $\begin{array}{l}\text { Zad. 1. Dzieci oglądały zdjęcia pejzaży C. Moneta i rozpoznawały } \\
\text { zawarte w nich emocje. }\end{array}$ \\
\hline Rozumienie emocji & $\begin{array}{l}\text { Zad. 2. Dzieci oglądały obrazki przedstawiające zdarzenia interper- } \\
\text { sonalne i wyobrażały sobie zmiany emocji. Antycypację uczuć } \\
\text { konceptualizowały w pracach plastycznych. }\end{array}$ \\
\hline Zarzqdzanie emocjami & $\begin{array}{l}\text { Zad. 3. Zarządzanie własnymi emocjami, dzieci uczestniczyły } \\
\text { w klasycznym eksperymencie społecznym W. Mischela }\end{array}$ \\
\cline { 2 - 2 } & $\begin{array}{l}\text { Zad. 4. Zarządzanie emocjami społecznymi, dzieci oglądały obrazki } \\
\text { przedstawiające zdarzenia interpersonalne, rozpoznawały zawarte } \\
\text { w nich emocje oraz podawały różne sposoby rozwiązania danej } \\
\text { sytuacji. }\end{array}$ \\
\hline
\end{tabular}

Przebieg badań:

Zad.1. Spostrzeganie emocji. Badania przeprowadziła studentka Paulina Stachniak w ramach pracy dyplomowej. Zbadała 20 sześciolatków: 10 dziewczynek i 10 chłopców. Starała się odpowiedzieć na pytanie: jak dzieci spostrzegają emocje zawarte w pejzażach

Cloude'a Moneta?

Zadaniem dzieci było wyobrażenie sobie, iż są wrażliwymi artystami, którzy odkrywają emocje dzieł malarskich.

Po prezentacji dzieła i zadaniu przez badającego pytań, dzieci miały określić nastrój dzieła. Dzieciom zaprezentowano następujące dzieła Cloude'a Moneta:

\begin{tabular}{|c|c|c|c|c|}
\hline Pejzaże C. Moneta & \multicolumn{4}{|c|}{ Spostrzeganie emocji przez dzieci } \\
\hline $\begin{array}{l}\text { Wschód stońca-dominowało spostrzeganie } \\
\text { ciekawości i smutku }\end{array}$ & $\begin{array}{l}\text { ciekawość } \\
\text { smutek } \\
\text { złość }\end{array}$ & $\begin{array}{l}-9 \\
-7 \\
-1\end{array}$ & $\begin{array}{l}\text { strach } \\
\text { radość }\end{array}$ & $\begin{array}{l}-1 \\
-2\end{array}$ \\
\hline Zielone fale - dominowało spostrzeganie strachu & $\begin{array}{l}\text { strach } \\
\text { smutek }\end{array}$ & $\begin{array}{l}-12 \\
-3\end{array}$ & $\begin{array}{l}\text { złość } \\
\text { ciekawość }\end{array}$ & $\begin{array}{l}-4 \\
-1\end{array}$ \\
\hline Parlament - dominowało spostrzeganie złości & $\begin{array}{l}\text { ztość } \\
\text { smutek }\end{array}$ & $\begin{array}{r}-10 \\
-\quad 3 \\
\end{array}$ & $\begin{array}{l}\text { strach } \\
\text { ciekawość }\end{array}$ & $\begin{array}{l}-6 \\
-1 \\
\end{array}$ \\
\hline $\begin{array}{l}\text { Pole tulipanów } w \text { Holandii - dominowało } \\
\text { spostrzeganie radości }\end{array}$ & $\begin{array}{l}\text { radość } \\
\text { ciekawość }\end{array}$ & $\begin{array}{r}-12 \\
-\quad 5\end{array}$ & $\begin{array}{l}\text { smutek } \\
\text { strach }\end{array}$ & $\begin{array}{l}-2 \\
-1\end{array}$ \\
\hline $\begin{array}{l}\text { Japoński ogród-dominowało spostrzeganie } \\
\text { radości }\end{array}$ & $\begin{array}{l}\text { radość } \\
\text { ciekawość }\end{array}$ & $\begin{array}{r}-12 \\
-\quad 5\end{array}$ & $\begin{array}{l}\text { strach } \\
\text { smutek }\end{array}$ & $\begin{array}{l}-2 \\
-1\end{array}$ \\
\hline
\end{tabular}


Wschód stońca - (ciekawość i smutek);

Co widzisz na obrazie? Jakie uczucia wywołuje u ciebie taki krajobraz?

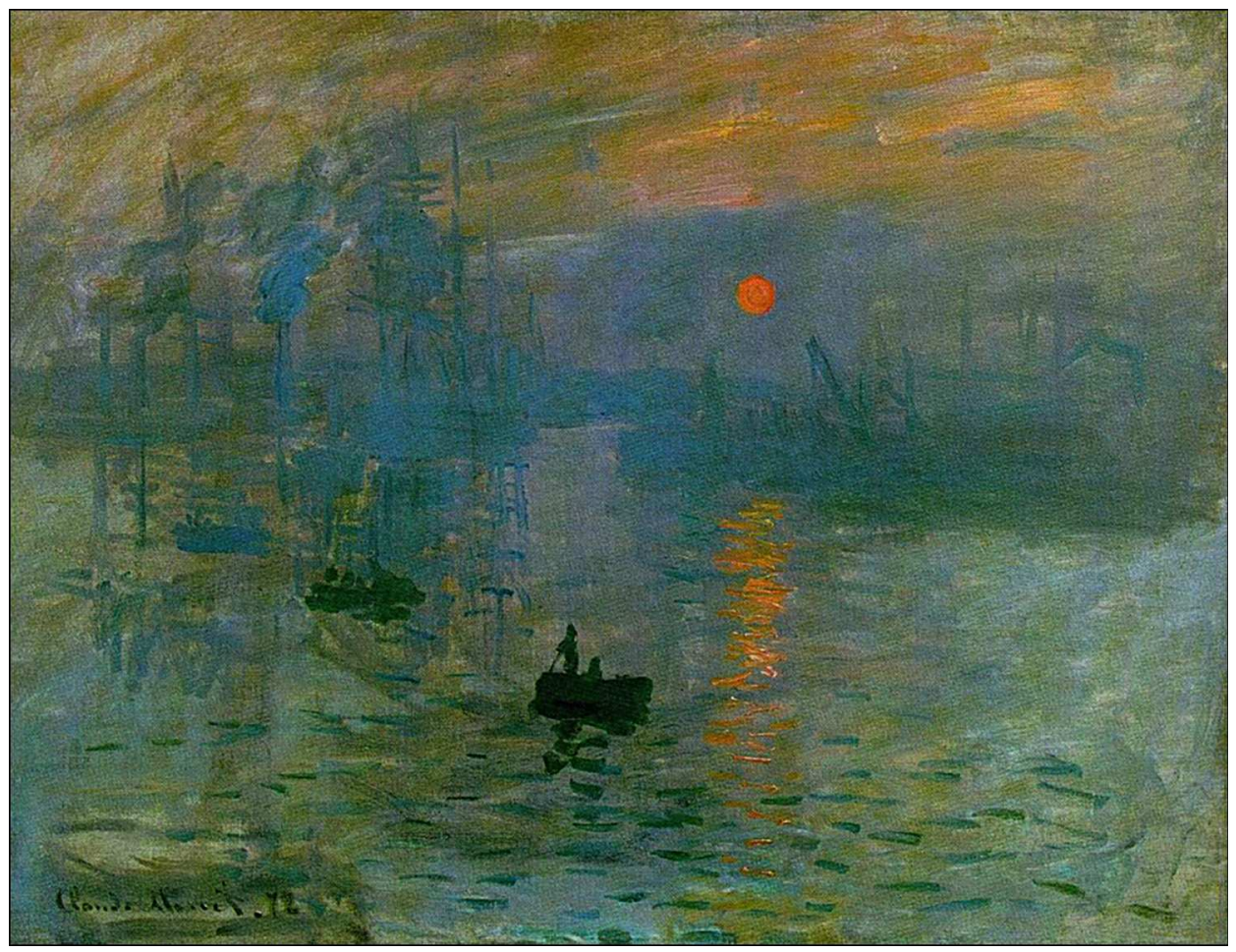


Zielone fale - (strach)

Co widzisz na obrazie? Jak myślisz, jak czuja się ludzie przebywający na statku?

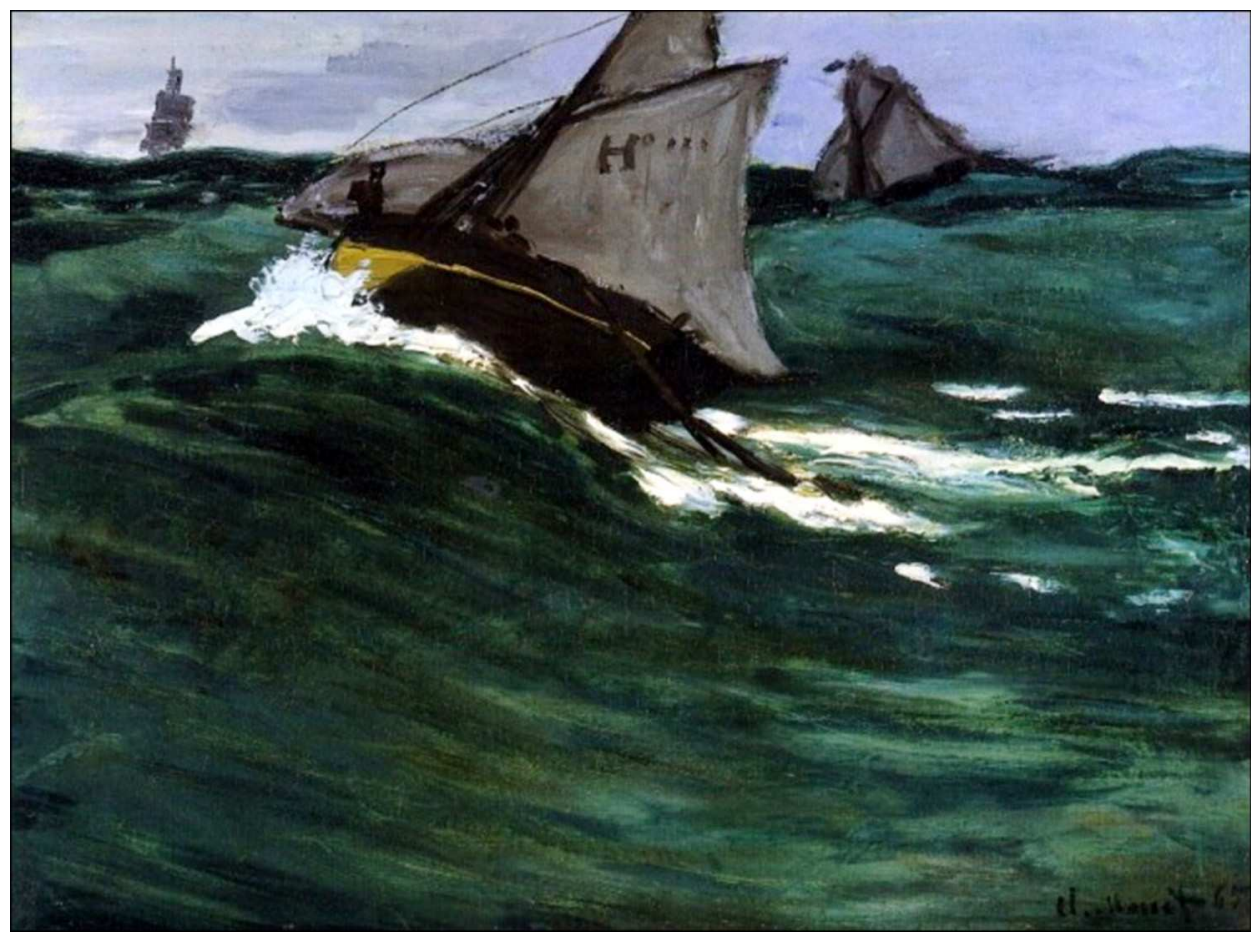


Parlament - (złość)

Jakie kolory widzisz na obrazie? Jak myślisz, jak czut się malarz tworzą go?

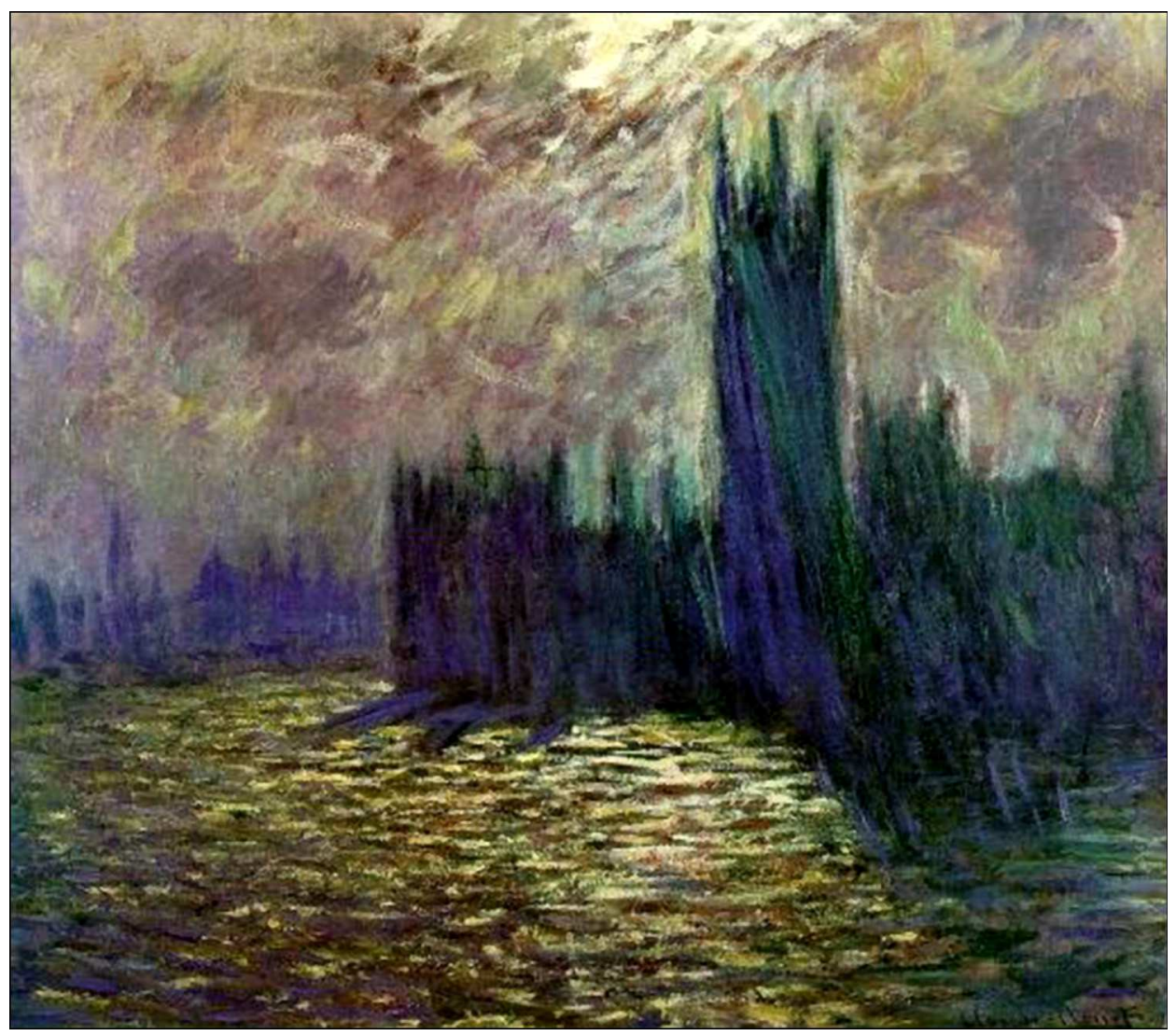


Pole tulipanów w Holandii - (radość)

Jaki nastrój wywotuje u ciebie ten obraz? Jak byś się czuł będac na tej tace?

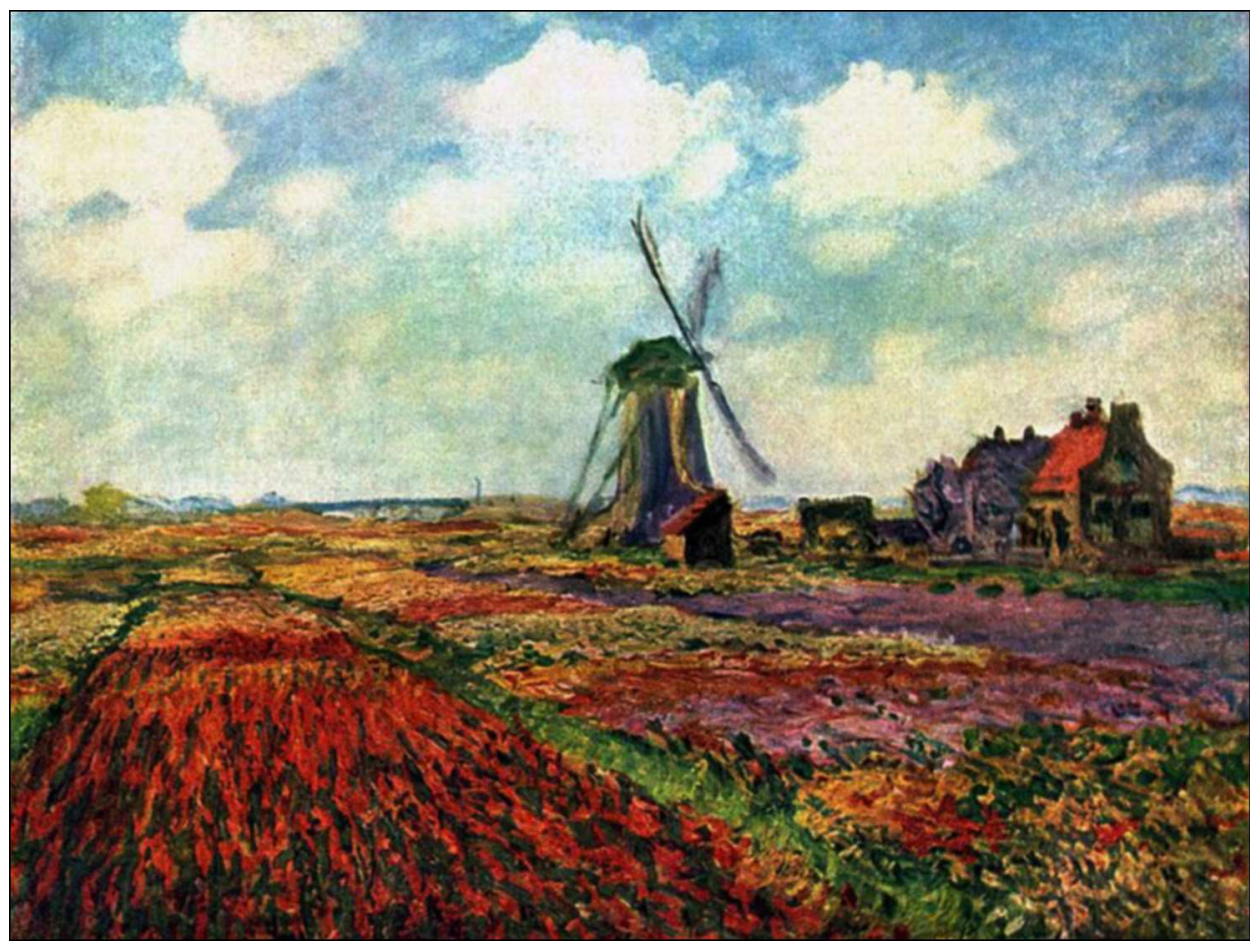


Japoński ogród - (radość)

Jaki jest ten obraz? Czy zastanawiasz się, co jest za mostkiem? Czy ten obraz nie jest bajkowy?

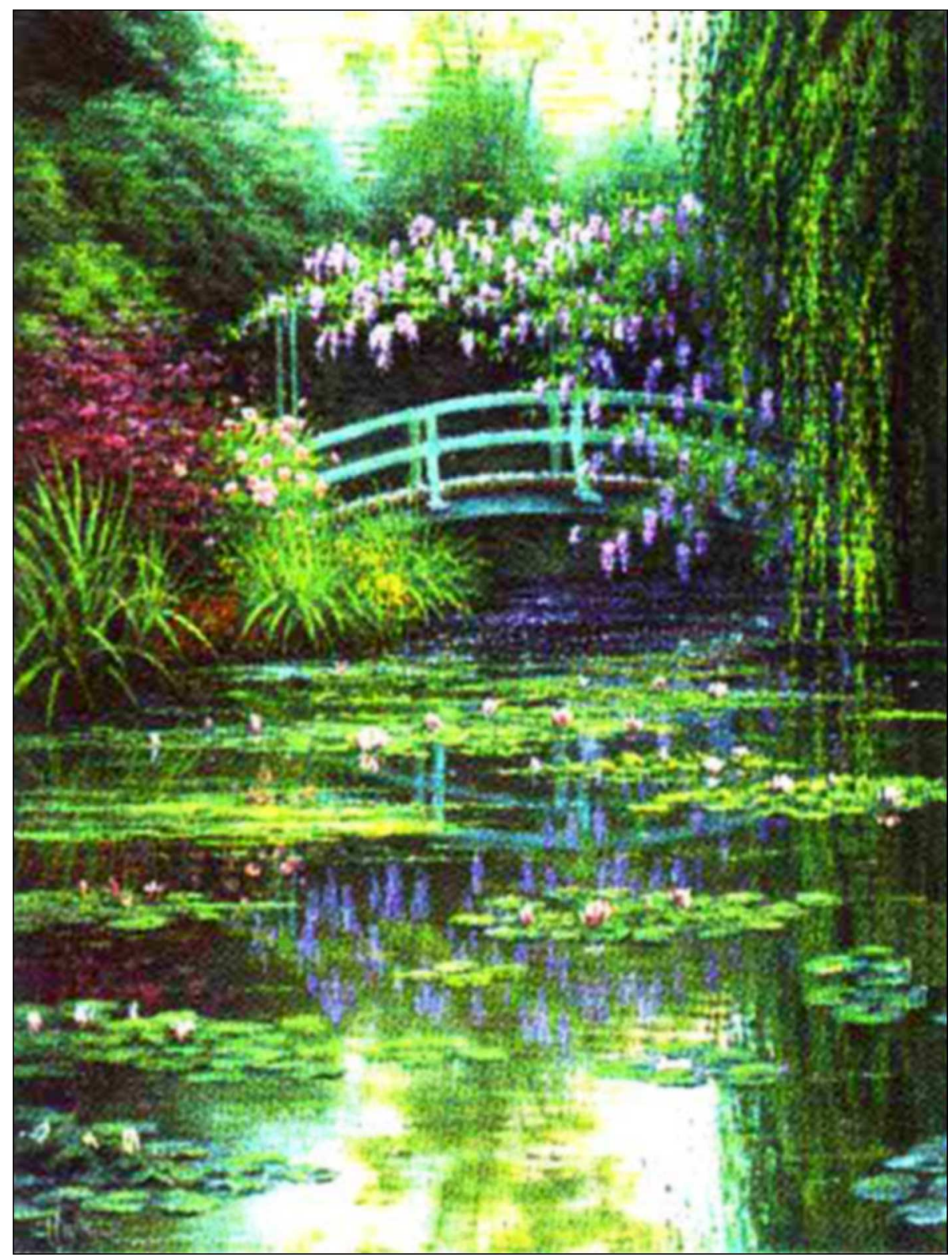




\section{Zad.2. Rozumienie emocji}

Badanym zaprezentowano obrazki ukazujące przeżywanie emocji przez dzieci w określonym kontekście. Ich zadaniem było rozpoznanie zawartych w nich emocji, ustosunkowanie się uczuciowe do prezentowanych zdarzeń oraz wymyślenie dalszego rozwoju uczuć dzieci względem siebie. Starano się odpowiedzieć na pytanie? Czy dzieci potrafią wyobrazić sobie zmianę uczuć?

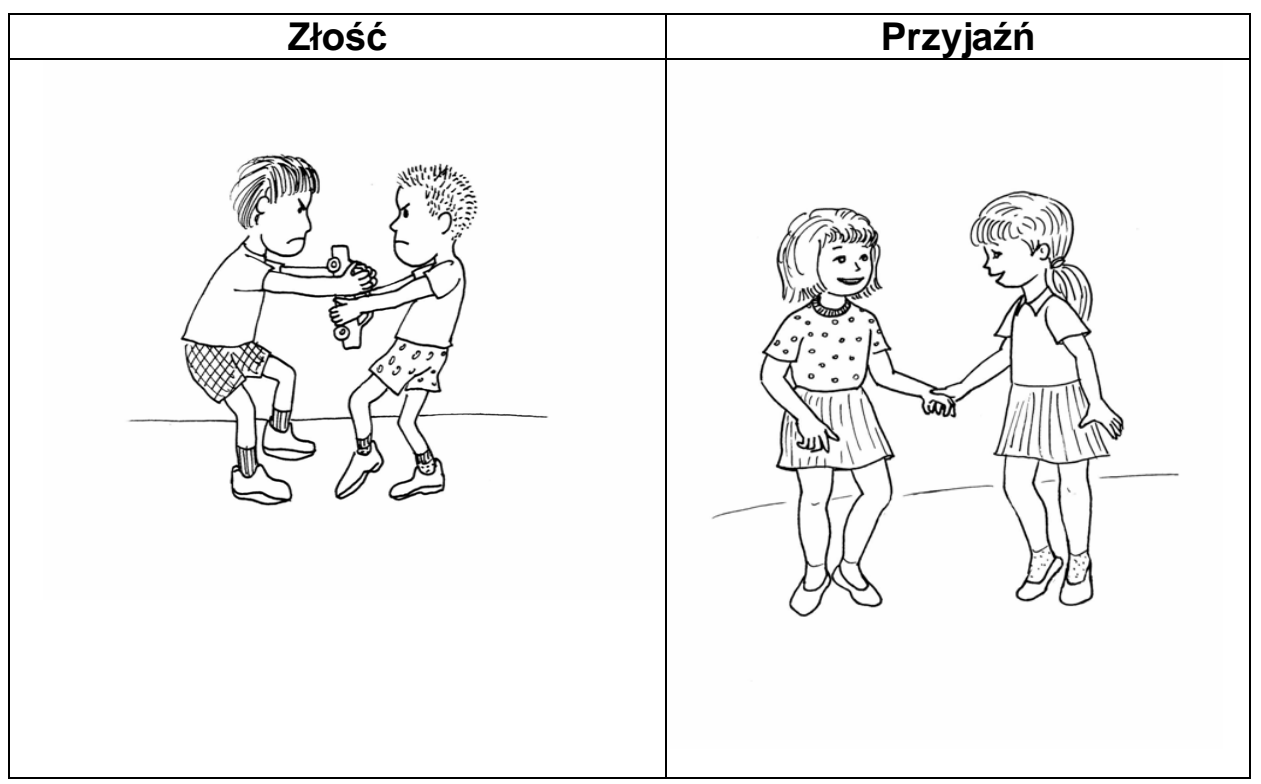

Instrukcja:

Przyjrzyj się obrazkowi $i$ powiedz, co czuja, (przeżywaja) ci chłopcy? (dziewczynki)?

Jakie emocje przeżywali oni wcześniej? -dlaczego tak myślisz?

Jakie emocje będq odczuwać dzieci w stosunku do siebie później?

Konkretyzacja plastyczna:

Narysuj, jakie emocje będq odczuwały dzieci do siebie później?

Wybrane przykłady prac plastycznych dzieci 


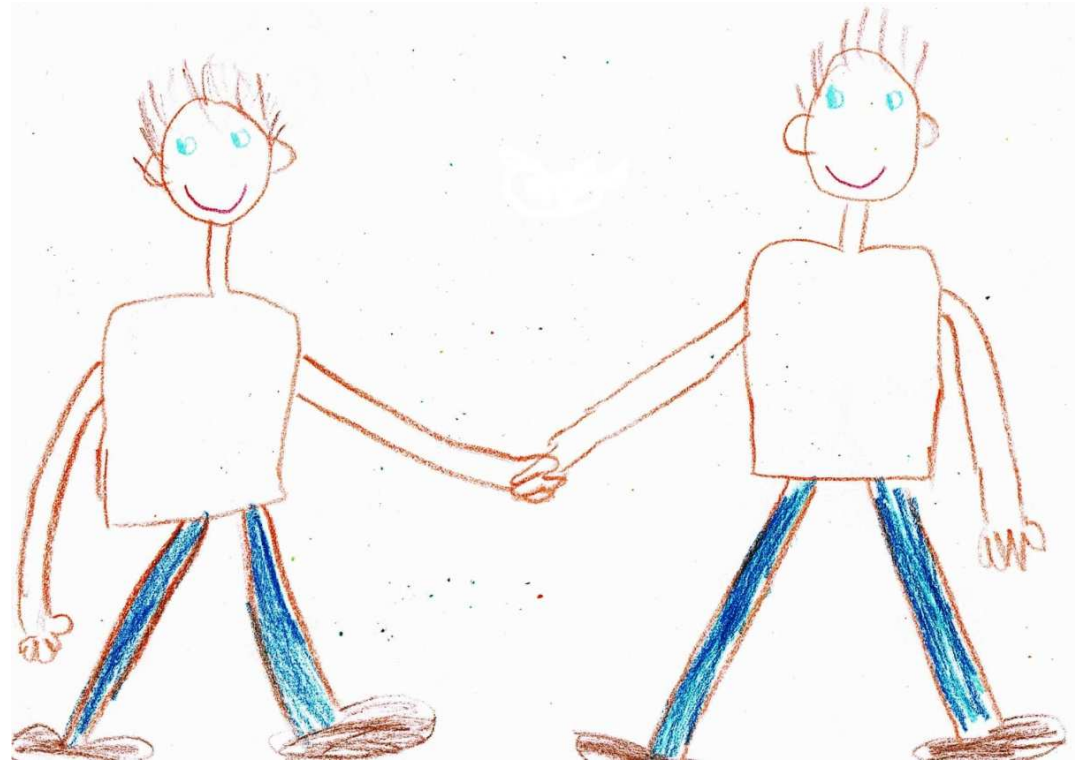

Rys. 1. Rysunek Adama: Będq chcieli zostać przyjaciótmi (w odniesieniu do złości)

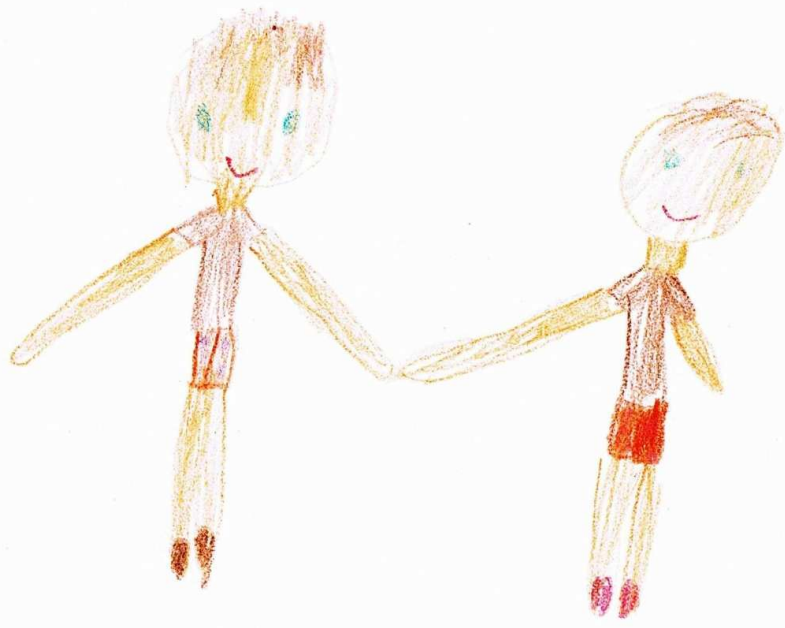

Rys. 2. Rysunek Julki: Będq czuć przyjaźń, jeden chce mu dać rękę na zgodę (w odniesieniu do złości) 


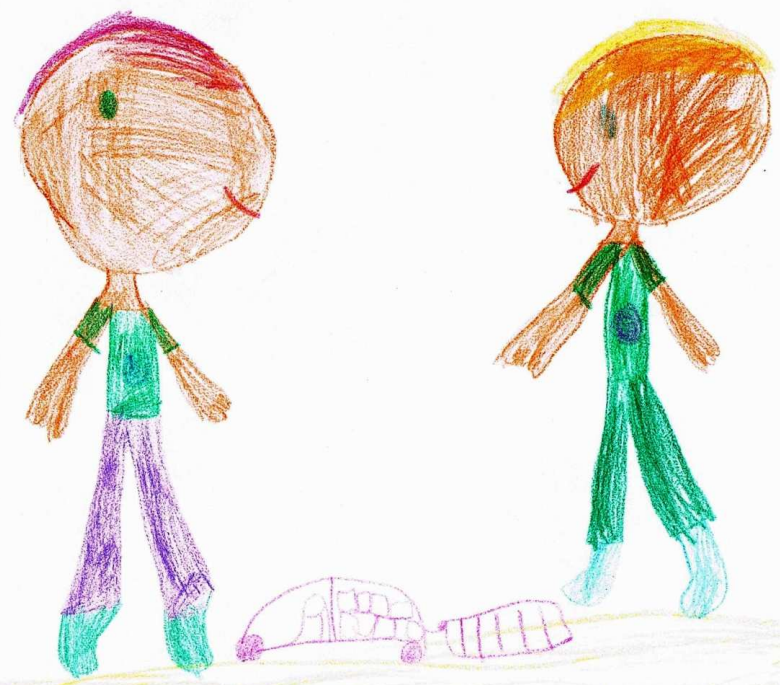

Rys.3. Rysunek Jagody: Przeprosili się i będq się bawić, (w odniesieniu do złości)
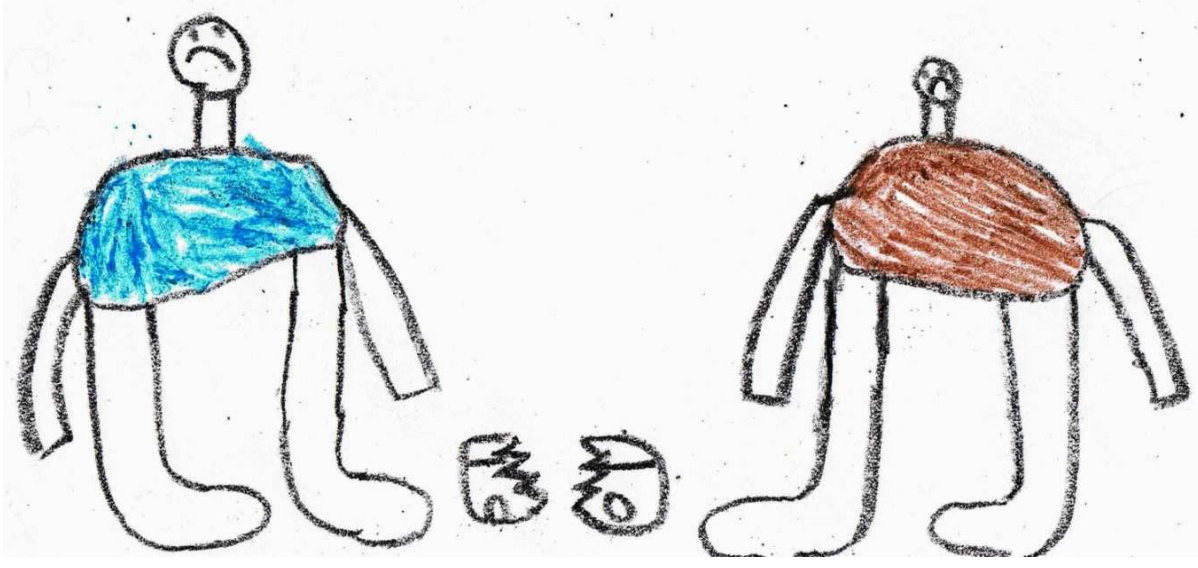

Rys.4. Rysunek Kacpra: Będa czuć smutek, bo auto może się złamać, (w odniesieniu do złości) 

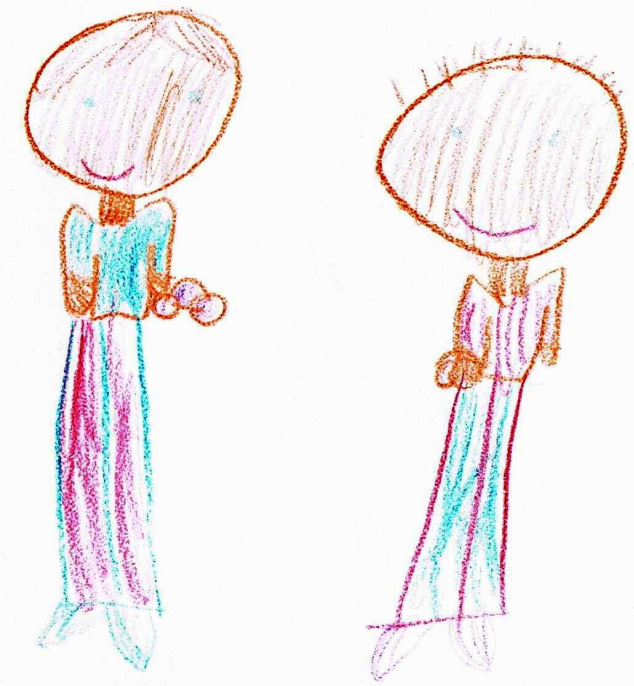

Rys. 5. Rysunek Oliwii: Będq się lubić, (w odniesieniu do złości)
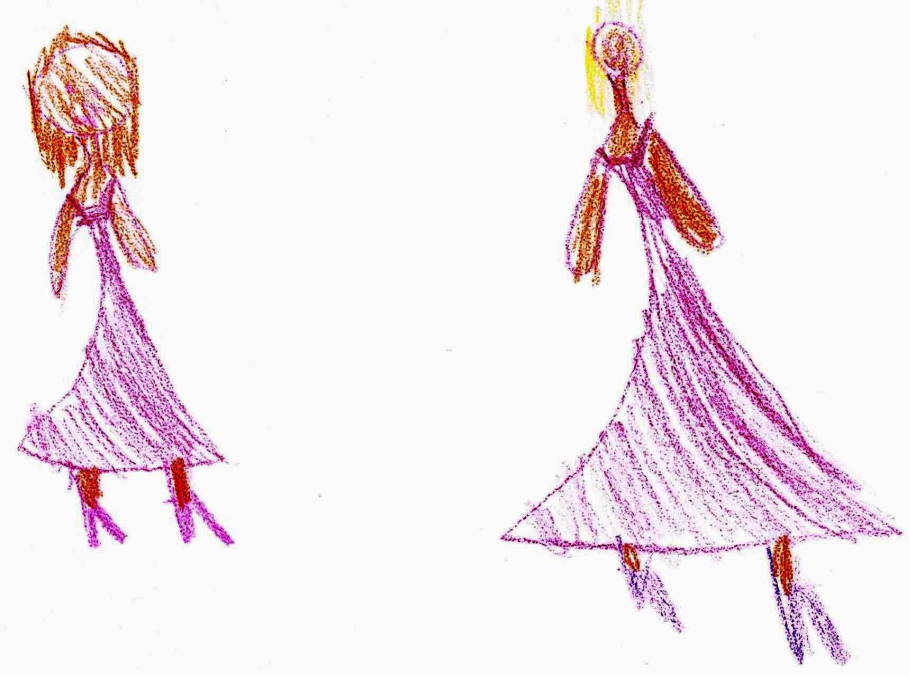

Rys 6. Rysunek Agnieszki: Później będa czuć smutek, (w odniesieniu do przyjaźni) 


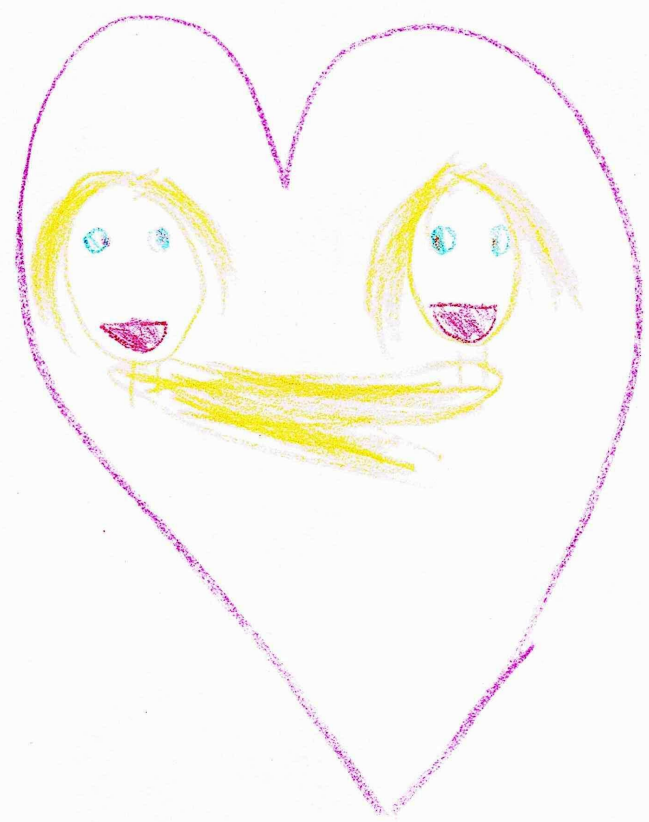

Rys. 7. Rysunek Adama: Będq czuć miłość, (w odniesieniu do przyjaźni)

Ocenę zebranego materiału ustalono na podstawie kategorii dotyczących zmian emocji:

Tabela 2. Kategorie zmian emocji w odniesieniu do ilustracji złości

\begin{tabular}{|l|c|}
\hline \multicolumn{1}{|c|}{ Kategorie zmian emocji } & Liczba dzieci \\
\hline Dziecko mówi, że nie wie, co wydarzyło się wcześniej & 6 \\
\hline Dziecko podaje przyczyny powstawania emocji & 14 \\
\hline Dziecko mówi, że nie wie jakie emocje będą odczuwały dzieci później & 1 \\
\hline $\begin{array}{l}\text { Dziecko mówi, że pojawią się emocje negatywne (smutek, zdenerwowanie, } \\
\text { złość) }\end{array}$ & 6 \\
\hline $\begin{array}{l}\text { Dziecko mówi, że pojawią się emocje pozytywne (radość, przyjaźń, wspólna } \\
\text { zabawa) }\end{array}$ & 13 \\
\hline
\end{tabular}

Tabela 3. Kategorie zmian emocji w odniesieniu do ilustracji przyjaźń:

\begin{tabular}{|l|c|}
\hline \multicolumn{1}{|c|}{ Kategorie zmian emocji } & Liczba dzieci \\
\hline Dziecko mówi, że nie wie co wydarzyło się wcześniej & 5 \\
\hline Dziecko podaje przyczyny powstawania emocji & 15 \\
\hline Dziecko mówi, że nie wie jakie emocje będą odczuwały dzieci później & 2 \\
\hline Dziecko mówi, że pojawia się emocje negatywne (smutek, złość) & 2 \\
\hline Dziecko mówi, że pojawia się emocje pozytywne (radość, miłość, przyjaźń) & 16 \\
\hline
\end{tabular}


Tabela 4. Określenie przyczyn powstawania emocji-wybrane odpowiedzi dzieci:

\begin{tabular}{|c|c|}
\hline Złość & $\begin{array}{l}\text { Julka: Jeden pierwszy wział samochód i się pokłócili } \\
\text { Klara: Jeden chtopiec zaczqu bawić się zabawkq a potem drugi } \\
\text { Oliwia: Kłócq się, bo jest jeden samochód }\end{array}$ \\
\hline Przyjaźń & $\begin{array}{l}\text { Adaś: Były złe, kłócity się, przestały i chciały się zaprzyjaźnić } \\
\text { Oliwia: Byty złe na siebie, bo się nie lubity } \\
\text { Natalka: Ładnie się bawity }\end{array}$ \\
\hline
\end{tabular}

Tabela 5. Zmiany emocji -wybrane odpowiedzi dzieci:

\begin{tabular}{|l|l|}
\hline Złość & $\begin{array}{l}\text { Patrycja: Później będq weseli, bo Pani przyniesie drugie autko } \\
\text { Kacper: Później będq czuli smutek, auto może się złamać } \\
\text { Julka: Będa czuć przyjaźń }\end{array}$ \\
\hline Przyjaźń & $\begin{array}{l}\text { Agnieszka: Smutek będq czuty później, } \\
\text { Maksio: Będq sie dzielić lalkami } \\
\text { Oliwia: Będq sobie pomagać }\end{array}$ \\
\hline
\end{tabular}

Zad.3. Zarzqdzanie wtasnymi emocjami (badania przeprowadziła studentka Paulina Stachniak w ramach pracy dyplomowej). Badano 20 sześciolatków: 10 dziewczynek i 10 chłopców. Każde dziecko otrzymało jednego cukierka. Zadaniem dziecka była realizacja polecenia: Nie można zjeść cukierka, aż do powrotu nauczyciela. Kto nie zje cukierka do powrotu nauczyciela dostanie w nagrodę dwa cukierki. Nauczyciel wrócit po 10 minutach.

Starano się odpowiedzieć na pytanie czy dziecko jest w stanie odroczyć mniejszą gratyfikację w celu osiągnięcia większej?

Przeprowadzono obserwację sytuacji eksperymentalnej na podstawie kategorii:

Dziecko:

- natychmiast zjada cukierek

- nie zjada cukierka

- czeka w skupieniu na powrót eksperymentatora

- stara się nie patrzeć na cukierek

- kładzie cukierek daleko od siebie lub odchodzi od stolika

Tabela 6. Zarządzanie własnymi emocjami

\begin{tabular}{|l|c|}
\hline \multicolumn{1}{|c|}{ Zachowania dzieci } & $\begin{array}{c}\text { Przejawiane zachowania } \\
\text { dzieci }\end{array}$ \\
\hline Dzieci, które zjadły cukierek & 8 \\
\hline Dzieci, które nie zjadły cukierka & 12 \\
\hline Dzieci, które wstały od stolika i kładą cukierek daleko od siebie & 7 \\
\hline Dzieci, które siedzą przy stoliku i starają się nie patrzeć na cukierek & 4 \\
\hline $\begin{array}{l}\text { Dzieci, które w skupieniu czekają na nauczyciela przy stoliku i patrza } \\
\text { na cukierek }\end{array}$ & 1 \\
\hline
\end{tabular}




\section{Zad. 4. Zarzadzanie emocjami społecznymi}

Dzieciom zaprezentowano obrazki ukazujące przeżywanie emocji przez człowieka w określonym kontekście.

Zadaniem dzieci było rozpoznanie zawartych w nich emocji i wyobrażenie sobie, że w nich uczestniczy. Następnie podanie sposobów zachowania, które byłyby skuteczne przy rozwiązaniu zobrazowanych problemów.

Starano się odpowiedzieć na pytanie czy dzieci potrafią podać sposoby zachowania służące rozwiązaniu określonych problemów angażujących innych ludzi?

Instrukcja:

Przyjrzyj się obrazkowi i powiedz co czuje, (przeżywa) ta dziewczynka?

Co byś zrobit, gdybyś ja teraz spotkat?

Co byś zrobit, żeby nie byta smutna (nie ptakata)?

Ocenę zebranego materiału ustalono na podstawie kategorii:

Dziecko mówi, że:

- nie wie co by zrobiło w określonej sytuacji

- podaje różne sposoby rozwiązania zaistniałego problemu

Wyniki badań:

Tabela 7. Zarządzanie emocjami innych

\begin{tabular}{|l|l|c|}
\hline \multicolumn{1}{|c|}{ Rodzaj pytania } & Wybrane odpowiedzi udzielone przez dzieci & $\begin{array}{c}\text { Liczba } \\
\text { dzieci }\end{array}$ \\
\hline $\begin{array}{l}\text { Co byś zrobiłla, by ta dziewczynka nie } \\
\text { była smutna? }\end{array}$ & $\begin{array}{l}\text { Nie wiem } \\
\text { Pocieszyłbym ja, naprawiłbym lalke, } \\
\text { rozweseliła bym jq }\end{array}$ & 7 \\
\hline $\begin{array}{l}\text { Co byś zrobiłla, żeby ten chłopiec nie } \\
\text { był przestraszony? }\end{array}$ & $\begin{array}{l}\text { Nie wiem } \\
\text { Spokojnie, to tylko pies, zabiłbym wilka, } \\
\text { ukrytbym chłopca w bezpiecznym miejscu }\end{array}$ & 13 \\
\hline $\begin{array}{l}\text { Co byś zrobiłla, żeby ci chłopcy nie byli } \\
\text { na siebie źli? }\end{array}$ & $\begin{array}{l}\text { Nie wiem } \\
\text { Pogodzitbym ich, żeby podali sobie ręce, } \\
\text { uspokoiłbym ich, dałbym im drugie auto }\end{array}$ & 10 \\
\hline $\begin{array}{l}\text { Co byś zrobiłla, żeby ten chłopiec nie } \\
\text { był radosny? }\end{array}$ & $\begin{array}{l}\text { Nie wiem } \\
\text { Bitbym go, zasmuciłbym go, można zabrać } \\
\text { mu prezent, ale ja bym tak nie robit }\end{array}$ & 12 \\
\hline $\begin{array}{l}\text { Co byś zrobiłla, żeby ten chłopiec nie } \\
\text { był zaciekawiony? }\end{array}$ & $\begin{array}{l}\text { Nie wiem } \\
\text { Wziatbym mu coś, co najbardziej lubi, } \\
\text { dałbym mu nieciekawy prezent, zabratbym } \\
\text { mu pudełko }\end{array}$ & 8 \\
\hline
\end{tabular}



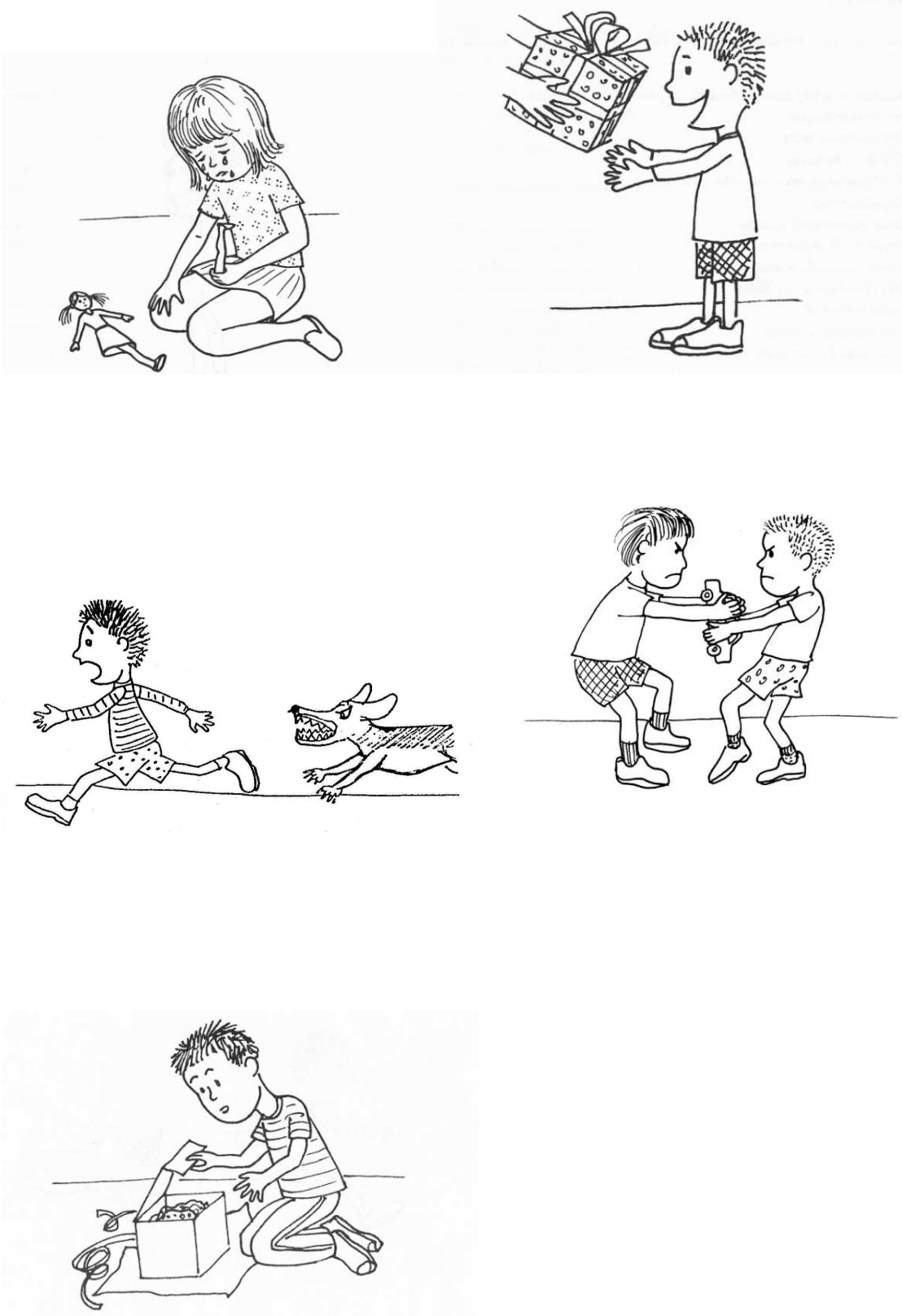

Prezentowane ilustracje pochodzą z książki Górecka-Mostowicz ${ }^{8}$

\footnotetext{
${ }^{8}$ B. Górecka-Mostowicz, Co dzieci wiedzq o emocjach, Kraków 2005.
} 
Analiza wyników badań $w$ odniesieniu do spostrzeganie emocji

Jak wynika z analizy każde dziecko potrafiło w indywidualny sposób odczytać nastrój pejzaży Moneta.

Rozumienie emocji

Zdolności dzieci do rozumienia informacji emocjonalnych przejawiały się w ich poziomie werbalizacji, jak również w połączeniu werbalizacji z wyobraźnią: dzieci podawały przyczyny powstawania emocji (reprodukcja), jak również wyobrażały sobie ich zmiany (antycypacja). Wskazywanie przyczyn posiadało charakter sytuacyjny, dzieci podawały najczęściej cechy kontekstowe (zewnętrzne).

Stwierdzono, iż dzieci posiadają utrwalony system społecznych oczekiwań w zakresie właściwych zachowań emocjonalnych. Wszystkie negatywnie oceniły zachowania chłopców, a pozytywnie zachowania dziewczynek. U badanych wystapiły pewne trudności w analizowaniu emocji reprodukcyjnych (6 osób nie podało przyczyn zachowań chłopców, a 5 osób - przyczyn zachowań dziewczynek). Natomiast dzieci dobrze radziły sobie w zakresie wymyślenia rozwiązania przedstawionych sytuacji społecznych. Analiza wypowiedzi przedszkolaków pozwala ocenić ich zdolność uświadamiania sobie logicznych konsekwencji zachowań interpersonalnych oraz umiejętność wyobrażeniowej antycypacji rozwiązań sytuacji problemowych i przyjacielskich.

\section{Zarządzanie własnymi emocjami}

Stwierdzono, iż dzieci znacząco różnią się w zakresie zdolności do odraczania własnych przyjemności. Tylko jedno dziecko w skupieniu czekało 10 minut na powrót nauczyciela, w celu uzykania zwielokrotnionej gratyfikacji (wówczas otrzymało drugi dodatkowy cukierek). Według E. Aronsona, odroczenie gratyfikacji wiąże się z automotywacja i samoregulacja (...) i powoduje więcej niż jedynie krótkoterminowe konsekwencje (np. zdobycie dodatkowego cukierka i dobrego samopoczucia). (...) Dzieci, które ujawnity większq samokontrole (...) ocenione byty przez swoje matki jako bardziej rozwinięte werbalnie, racjonalne, uważne, zdolne do koncentracji, pewne siebie, oraz wykazywaty mniejsze sktonności do popadania w przygnębienie w obliczu niepowodzenia ${ }^{10}$.

\section{Zarządzanie emocjami społecznymi}

Jak wynika $\mathrm{z}$ analizy przeprowadzonych badań, dzieci potrafiły podać własne rozwiązania sytuacji problemowych związanych $\mathrm{z}$ funkcjonowaniem emocjonalnym innych. W większości opisywały uczucia innych i wymyślały sposoby pomagania im.

${ }^{9}$ Za: M. Śmieja, J. Orzechowski, Inteligencja emocjonalna. Fakty, mity, kontrowersje, Warszawa 2008, s. 83.

${ }^{10}$ Tamże, s. 83. 


\section{Wnioski}

Podstawowy cel wychowania emocjonalnego przedszkolaków upatruję we wspomaganiu rozwoju ich inteligencji emocjonalnej, rozumianej jako zbiór zdolności służących do odczytywania informacji emocjonalnych. Należy tak organizować środowisko przedszkolne, aby stwarzać dla przedszkolaków warunki do dekodowania emocji na podstawie analiz różnorodnych kontekstów sytuacyjnych oraz recepcji dzieł literackich, malarskich i muzycznych.

Przede wszystkim należy kształcić procesy poznawcze: spostrzeganie, uwagę, pamięć oraz myślenie i mowę. Związki pomiędzy emocjami a wymienionymi procesami poznawczymi są złożone i wielorakie. I tak na przykład badania pamięci małych dzieci ${ }^{11}$ dowodzą, iż dziecko lepiej pamięta zdarzenia, w których było zaangażowane emocjonalnie, niż zdarzenia obojętne. $\mathrm{Z}$ procesami pamięci łączą się procesy spostrzegania i uwagi, procesy te oddziaływają na siebie we wczesnej ontogenezie: spostrzeganie podtrzymywane jest uwagą, która jednocześnie aktywizuje procesy pamięciowe. Dziecko zwracając uwagę na sygnały świadczące o przeżywaniu emocji przez innych, równocześnie kontroluje sygnały wysyłane przez siebie. Buduje wiedzę o sposobach ekspresji emocji i uczuć w połączeniu z rejestracją zachowań innych. Tworzy swoistą umysłową siatkę poznawczą dotyczącą emocji - emocjogram, czyli swoistą mapę emocjonalnych odniesień w stosunku do innych ludzi. Rola dorosłego powinna polegać na uświadomieniu dzieciom wartości relacji międzyludzkich i podkreślaniu ich znaczenia w życiu człowieka.

Sądzę, że nie należy narzucać dzieciom „gotowego” wzorca interpretacji zachowań emocjonalnych, lecz powinniśmy wyjść od opisów dziecięcych i na ich bazie budować reprezentację emocji.

BARBARA GÓRECKA-MOSTOWICZ

\section{Creating the understanding of the emotional life sphere of infants - new solutions}

The elaborate concerns the problems with understanding of the emotional life sphere by the young children in the infant school. It was conveyed the measurement of the Emotional Intelligence of infants within the limits of the model MSCEIT (Marc. A. Brackett, P. Salovey, 2008).

In the range of: perceiving, understanding and managing of the emotions. The data concerning the conceptualization of the feelings in the language and art works of the six years old children. The results of such research allowed us to estimate the way in which they interpret the

${ }^{11}$ M. Jagodzińska, Rozwój pamięci w dzieciństwie, Gdańsk 2003. 
events that cause our emotions and also how they emotionally take an attitude towards them. It was established that the proposals of the solutions connecting problematic situations were based on the children's opinions. There were proposed ways of emotional upbringing of infants in the following spheres:

- Creating the emotional insight that realizing itself in the skill of reading own emotions (drawing up the map of emotions which were experienced by them)

- Creating the understanding of other people and the social world (drawing up the emotiogram of the interpersonal connections). 